\title{
Co-offending and Bribery: The Recruitment of Participants to Corrupt Schemes and the Implications for Prevention
}

Mark Button, David Shepherd and Dean Blackbourn

Centre for Counter Fraud Studies, University of Portsmouth, PO1 2HY, UK.

Published in Security Journal on $29^{\text {th }}$ April, 2018.

Abstract This paper explores the rarely researched areas of co-offending and bribery. Based upon interviews with six persons convicted of bribery-related offences and other cases in the public domain, the paper explores how previously 'clean' persons are recruited to corrupt schemes. In doing so, the paper draws on Reason's resident pathogen theory on safety and uniquely applies it to bribery. The paper also identifies common recruitment techniques used by corruptors and proposes pathogen network analysis as a novel method for enhancing bribery prevention.

Key Words Bribery, corruption, prevention, resident pathogen theory

\section{Introduction}

Academic research into corruption has for decades skirted around a fundamental question: how is a corrupt relationship initiated? How does the corruptor secure the co-operation of the other party without triggering disastrous repercussions such as a complaint to the police? How do they determine if the other party is corrupt or is potentially corrupt? This challenge was illustrated in one of the first convictions under the UK Bribery Act 2010, when a University of Bath student was jailed for trying to bribe his professor (BBC, 2013). Yang Li had received a fail mark for his Master's degree dissertation and arranged a meeting with Professor Graves. Li arrived at the meeting armed with a pistol and placed $£ 5,000$ in cash on the professor's desk, declaring "I am a businessman...you can keep the money if you give me a pass mark and I won't bother you again." Li's attempt failed, he was reported to the authorities and ended up in jail. Such exposures and prosecutions are rare, but the evidence suggests that bribery is a far more significant problem than the detected figures suggest (OECD, 2014). This implies that many corruptors are successful in luring others into their schemes and only a few fail as spectacularly as Mr Li. This paper seeks to explore the recruitment of persons into corruption. The article is not concerned with fleeting corrupt relationships such as when a police officer demands a payment to avoid issuing a penalty ticket. The research focuses on more enduring or substantive relationships. The paper builds upon Reason's (2000b) resident pathogen theory to explain the conditions necessary for bribery to occur and then, drawing upon the interviews from 
this research and other information in the public domain, explore how people are recruited into corrupt schemes. It does not, however, explore why people become corrupt (for those interested in this see Schoepfer et al, 2014; Gottschalk, 2017). The paper introduces the pathogen network as a novel method for researchers and practitioners to visually analyse corrupt or potentially corrupt situations. Firstly, however, the paper sets out the context of bribery and outlines the research methods.

\section{Bribery and corruption in context}

The precise scale of bribery is unknown due to undetected and unreported cases, but has been estimated at \$1 trillion paid annually worldwide (Gottschalk and Tcherni-Buzzeo, 2017; OECD, 2014). A European Commission study estimated that 1 in 5 public procurement contracts are corrupt and the average loss to corruption is $3.65 \%$ (EC, 2013). More than two-thirds of countries score below 50 on Transparency International's corruption perceptions index; the UK is in 8th place with a score of 82 (Transparency International, 2018). The corrosive extent of the problem has energised the campaigns of transnational organisations, including Transparency International, the Organisation for Economic Development and the United Nations. Many countries have responded to these entreaties by enacting anti-bribery legislation (Gordon and Miyake, 2000). The UK government unified previous legislation with the introduction of the Bribery Act 2010.

There is a corpus of scholarly work which addresses the broad field of white-collar crime and fraud, starting with the seminal research of Sutherland (1940) and Cressey (1953), see Van Slyke et al (2016) for a general introduction. There is also a reasonable body of research drawn from several academic disciplines which explores the narrower issue of corruption and anti-corruption policies (Brytting et al, 2011; Eicher, 2012; Kubbe and Engelbert, 2018). There is, however, very little research into why and how individuals engage in corruption (Mazar et al, 2015; Welsh et al, 2015). Research which specifically addresses bribery is rare. Köbis et al (2016) used psychological experiments to explore the propensity to bribe. Hernandez and McGee (2013) highlighted significant cultural variations in the public tolerance of bribery. Goldstraw-White and Gill (2016) have explored how organisations in the Middle East cope with the risk of Bribery. Lord (2014) has focused on transnational bribery and law enforcement. Lord and Levi (2016) explored how the situational crime prevention approach could be deployed to frustrate the financing of corporate bribery. The authors are not aware of any research based on interviews with convicted bribe payers and takers other 
than Gray (2013), who drew upon five publicly broadcast interviews with Jack Abramoff, a prominent political lobbyist, convicted for multiple acts of fraud and corruption.

A distinguishing feature of bribery is that it always involves co-offending between the bribe payer and the bribe receiver. Often these conspiratorial relationships are uncomplicated and fleeting, particularly in countries where petty corruption is endemic: a small sum of money or other benefit is paid to gain preferential treatment in, for example, expediting bureaucracy, smuggling, seeking favourable regulatory decisions or to win contracts (Fletcher and Hermann, 2012; Graycar and Sidebottom, 2012). The first conviction under the Bribery Act 2010 in the UK involved short-term, transactional relationships with traffic offenders: Munir Patel was a court clerk who received $£ 500$ a time bribes to refrain from recording court summonses into the judicial database (BBC, 2011). However, many relationships are more considered, complex, enduring and sometimes complicated by the involvement of occupational fraud, for example, Siemens (US Department of Justice, 2008) and the Crown employee, Ronald Harper (CPS, 2016). In these cases the supplier negotiates the value of the inducement and then conspires with the customer's representative to fraudulently inflate the value of contracts in order to fund the bribe (United Nations, 2013, p25; Graycar and Prenzler, 2013, p101).

There is little research literature which examines how these co-offending, corrupt relationships arise, whether fleeting or persistent. As van Mastrigt and Farrington (2009, p552) note, '...relatively few studies of co-offending exist, and the majority have been limited to examining juvenile samples.' Sub-cultural theories, most notably differential association, promulgate explanations of the pathways to crime based on social learning in environments with degraded normative values (Ashforth and Annand, 2003; Sutherland, Cressey and Luckenbill, 1992, p88). Similarly, Ditton (1977) and Mars (1982) found that corrupted organisational cultures and toxic associations encourage fraudulent behaviour in organisations. Free and Murphy (2015) highlighted the salience of social bonds in the aetiology of fraud conspiracies.

Seeking inspiration from alternative scholarly silos which explore failures of organisational governance, there is a rich body of research dealing with safety, accidents, disasters, systems and human errors in decision-making (Perrow, 2011; Reason, 2000b; Toft and Reynolds, 1997). The literature suggests failures in organisational systems resulting from the fallibility of technical and human elements are inevitable, particularly when they converge. Reason (2000b) describes such unseen, lurking dangers as 'resident pathogens'. These latent dangers could include poor design, 
faulty technology, inadequate management systems and poorly trained staff. In isolation, such resident pathogens may cause no problems, but in combination they may lead to a disaster. Using a sliced Swiss cheese metaphor, Reason (2000a, p769), illustrates these latent conditions as holes in an organisation's defences and safety failures occur when the holes in the slices align to permit "a trajectory of accident opportunity". The security analogies between safety and workplace crime suggest that the pathogen concept has utility in analysing bribery and other white-collar crimes. It does, however, require a significant additional ingredient, the human pathogen. In addition to the resident pathogens which fail to prevent bribery, there also needs to be at least one person who deliberately initiates the bribery and at least one other who agrees to participate.

The proposition is that offending occurs when pathogens converge in time and place and are sufficiently stimulated. One can infer from Cressey's (1953) fraud triangle that occupational fraud will occur when two pathogens coincide: inadequate security governance providing an opportunity and a financially distressed, psychologically prepared individual seeking a solution to his or her woes. The fraud diamond model (Wolfe and Hermanson, 2004) suggests a third pathogen: the presence of a capable, coercive offender. This paper builds on Reason's safety ideas to analyse the co-offending offence of bribery building upon the pathogen concept. Before these ideas are explored in more depth the methods used for this research will be first considered.

\section{Methods}

This research is based upon interviews conducted in 2014 with offenders convicted of bribery offences in six unrelated cases. Three of the participants were commercial bribe payers and three were public officers who received or were expecting bribes. Online searches of media outlets, regulators and commercial people tracing tools identified 165 fraud and bribery offenders convicted between 2004 and 2013. Invitation letters were sent to all the 165 offenders. The approach secured 13 positive responses and a further four through their social networks. Eleven were fraudsters and six were involved in bribery. The relevant details of the six bribery participants (from six separate cases) are set out in Table 1. Although six is a small sample, Gray (2013) demonstrated that examining the insider account of a single individual is sufficient to generate constructive insights. The majority of studies based on interviews with white-collar offenders have recruited and accessed participants in prison or under the auspices of probation services (Benson, 1990; Benson and Cullen, 1988; Cressey, 1953; Goldstraw-White, 2012). The risk associated with this approach is the potential influence of a form of on-stage effect (Kalof et al, 2008, p159) in that the offender is motivated to impress the officialdom and may '...obscure the truth of their crime in order to gain favours' (Copes 
and Hochstetler, 2010, p52), although this is not to suggest those outside prison may wish to impress, it is just the pressure to do so is less. There is also a real practical problem in recruiting research participants in prison or probation: in 2015 in the UK just two prosecutions were brought for bribery and 49 for misconduct in public office, a charge more often used for corrupt public officials (MoJ, 2016). The participants in the present research were all interviewed after their release from prison and supervision by the probation services. Two of the offenders, Carl and Carole, were prison employees and had been charged with misconduct in public office. The paper also draws upon data from publicly reported cases of bribe payers and takers.

Although the statistically small number of participants limits the extent to which the results can be generalized, they do offer an insight into how those relationships are formed. The small sample size has also narrowed the types of bribery situations and actors. The research excludes, for example, fleeting petty corruption relationships and high level political corruption. It also excludes the important role of intermediary facilitators. Finally, though the methods sought to escape any influence of the penal institutions, the risk remained that participants chose to obscure some aspects of their roles in their proven crimes.

Table 1 about here

\section{A Typology of Bribery}

Describing bribery is simple: person A (or persons) gives person B (or persons) money or some other form of value to secure a gain from the improper performance of person B. For example, a speeding motorist gives a police officer $f 50$ (gain) to not issue a speeding ticket, or a salesmen gives a buyer $f 1,000$ (gain) to win a contract. However, defining the boundaries of the offence is not always so straightforward because it intersects with fraud, extortion and clientelism (Transparency International, u.d.). Understanding bribery is also fraught with the difficulties of identifying who is to blame, who is the beneficiary, who is the victim and what their respective roles are. The problem is further compounded in the international context by legal and cultural variations (Melgar et al, 2010). The reformative efforts of transnational organisations focus on controlling the active bribery perpetrated by international corporations (Eicher, 2012, p15), thus diminishing the role of the bribe takers. White-collar criminologists similarly tend to avert their attention from those who demand favours and focus on the criminogenic nature of capitalist corporations (Coleman, 1992). This emphasis on the egregiousness of the briber rather than the bribee may explain why bribe paying is 
often labelled 'active bribery' and bribe receiving is labelled 'passive bribery' (OECD, 2011). Confusingly, Burke (2010, p17) uses the same labels in a completely different way: he describes 'active bribery' as bribery to obtain favourable outcomes, for example to win contracts, and 'passive bribery' as corrupt payments to avoid unfavourable outcomes, for example sanctions or punishment. Eicher (2012) differentiated between public corruption, for example bribing a public officer, and private corruption, such as when a company manager breaches his duties to arrange a bribe for his personal gain.

This typological confusion, lack of research and the inexperience of some judiciaries is bound to contribute to the cultural and legal variations and lead to perplexing, inequitable outcomes. The German authorities jailed Gerhard Gribkowsky for $8 \frac{1}{2}$ years for accepting bribes from Bernie Ecclestone, the CEO of F1, but Ecclestone avoided conviction whilst admitting paying \$44 million to prevent exposure of his dubious tax affairs (Le Blond, 2014). The participants' cases in the present research followed a similar pattern. Brian, Harvey and Phil were convicted of paying bribes but their counterpart recipients escaped prosecution; the three public officials were convicted, but the bribers escaped sanction. The typological framework set out below resolved this confusion to bring clarity to the research analysis.

- Briber - a person who pays a bribe

- Assertive briber - a person who makes the first approach by offering a bribe

- Submissive briber - a person who submits to a demand for a bribe from an assertive bribee

- Bribee - a person who receives a bribe

- Assertive bribee - a person who makes the first approach by demanding a bribe

- Submissive bribee - a person who agrees to the offer of a bribe from an assertive briber

- Facilitator - a person who facilitates the bribe and is independent of the briber and the bribee

- Public bribery - paying bribes to public officials for bureaucratic, regulatory or commercial contract purposes

- Commercial bribery - business to business bribery

\section{Metaphor of pathogens}

The metaphor of pathogens suggested by Reason (2000b) is an interactionist idea which recognises the social context of the organisation. It highlights the potential for safety failures arising from the 
structures, practices, norms and scripts embedded in the organisation's culture and systems of selfcontrol. The notion is equally applicable to other areas of organisational practices, such as quality, environmental control, bribery and corruption. Referencing the typology previously set out, we can define three types of bribery pathogens. For a bribe to occur there must be a convergence of at least three pathogens and at least two types. There must be a human 'corruptor pathogen', a 'resident pathogen' within the organisational systems and the third pathogen must be either a 'submissive pathogen' or a second 'corruptor pathogen'.

\section{Corruptor pathogen}

The corruptor pathogen is the predatory parasite who initiates the corrupt relationship, whether an assertive briber or an assertive bribee. It may be a person seeking private gains or to benefit others, their company or community. An example is a company manager who bribes a buyer to secure a contract. In the reverse case, a corruptor bribee pathogen is the manager who demands a bribe for awarding a contract. A more extreme instance involves the abuse of power and extortion: knowing that the supplier's business is dependent on the relationship, the corruptor bribe threatens to cut off the supply arrangement unless a bribe is paid.

\section{Submissive pathogen}

The submissive pathogen, whether the briber or the bribee, is the person who is sufficiently motivated to submit to the solicitation of the corruptor pathogen. Again, the submissive pathogen may be a person seeking private gain or for others. It may be a bribee motivated by the lure of easy money, or an individual who is offered respite from personal financial strains, or a victim of extortion. It is also the businessman who rationally calculates that he has, for the sake of his business, no alternative and consents to corrupt demands.

\section{Resident pathogen}

Resident pathogens are the weaknesses lurking in organisational structures, policies, norms, systems of control and routine activities. They are implicit in the opportunity limb of Cressey's (1953) fraud model: the shortcomings exploited by both bribers and bribees using their insider knowledge and expertise. Common examples are inadequate vendor appraisals, ineffective recruitment screening, superficial control of transactions and self-authorisation of expenditure (Tunley et al, 2018). Resident pathogens are not restricted to the systems of oversight, they also include factors which promote criminal acts, for instance, undue performance pressures and perverse incentives (MoJ, 2011). In more extreme circumstances, bribery is so deeply embedded in an organisation's cultural 
norms that the system is not just infected by pathogens, the entire system can be regarded as the resident pathogen.

\section{The corruption pathogen model}

Despite its limits (Schuchter and Levi, 2013; Wolfe and Hermanson, 2004), the fraud triangle paradigm is enduring partly due to its heuristic simplicity and because it lends itself to graphical presentation. The pathogen model extends this simple approach using social network techniques. Vicsek et al (2016) provide a brief overview of social network methods, including approaches which incorporate cultural aspects, concepts, categories and narratives as network nodes (see also Carley, 1997). Whilst there is some precedence in applying network techniques to corruption (Nash et al, 2017; Peoples and Sutton, 2015), a formal, yet flexible, visualisation framework is unique.

Figure 1 sets out a model network for the classic contractual corruption, where the nodes represent an external assertive briber (C) who corrupts a customer's employee (S) by exploiting the organisation's resident pathogens $(\mathrm{R})$. The submissive pathogen is co-located with the resident pathogens inside the organisation's boundary, whilst the corruptor pathogen sits outside. In circumstances where the corruptor pathogen is an assertive bribee within the customer organisation, the positions of the corruptor and submissive pathogen labels are exchanged.

Figure 1 about here

The same approach can be used to map the pathogen links within an organisation. Figure 2 draws on the experience of the prison officer, Carl, from this study to illustrate the situational pathway to crime: a cocktail of resident pathogens $(\mathrm{R})$, coercive internal and external corruptor pathogens (C-I and C-E) and Carl, the submissive internal pathogen (S). The resident pathogens (R) are scaled in the figure to represent their assumed relative salience to the defensive vulnerabilities of the prison.

Figure 2 about here

The pathogen network can be as extended and complex as the analysis requires to understand the interactions between the actors and the systems, environments, routine activities, rules, norms and shared rationalisations. It can be configured according to the requirements of the selected unit of 
analysis. At the person level, the technique can be used to examine the pathogenic relationships between employees, systems, situations and external agents. Although this article has not explored the role of facilitators, whether intermediaries or professional advisors (Middleton and Levi, 2015), they can easily be incorporated. It can assist in visualising how the convergence of pathogens creates a contagion which infects a corporate entity. At the organisational level, the method supports the examination of relationships between organisations, marketplaces and regulators. With careful application, the model has the capacity to further our understanding of the pathology of organisations (Slapper and Tombs, 1999, p110).

Having introduced the pathogen concept, this paper will now examine the proximal pathways to the act of bribery, the insidious circumstances, dialogue and scripts which precede the agreement to cooffend. The analysis employs the pathogen metaphor to examine the crime situations using insights from the research interviews and cases in the public domain. The discussion primarily focuses on the social interactions which enable corruptors to recruit participants into their illegal conspiracies.

\section{Recruiting a submissive or other corruptor pathogen}

The first stage for the corruptor pathogen is to identify the potential target to corrupt. This is usually straightforward, though may be more difficult in complex procurements involving multiple actors. However, once a corruptor has identified the relevant decision-maker and important influencer, he is typically unsure whether the target can be corrupted, whether an approach would preclude him from bidding for the contract, or even that he might be reported to the relevant authorities. The more significant challenge is to then determine if the person can be turned (a latent submissive pathogen) or already is corrupt (a previously activated submissive or corruptor pathogen). The research has identified a number of strategies used by corruptor pathogens.

\section{Profiling a target}

In the Li case discussed earlier there was just one potential submissive pathogen, Li's professor, and Li made a poor assessment which led to serious consequences. However, corruptors are often presented with a choice of targets. Agents of illegal gambling gangs have a choice of thousands of sportsmen and women. English cricketer Mervyn Westfield was successfully targeted by his friend, Danish Kaneira, in a 'spot-fixing' scam because he was young, impressionable and easily influenced (Wilson, 2014). Prison employee, James Almond, was targeted by an inmate to smuggle mobile phones into prison because he was a vulnerable junior employee with only a few months of service and had not received any training in dealing with prisoners as his job was solely to escort contractors 
into and out of the prison (Shaw, 2017). Similarly, research participant, Walter, was just one member of a local authority planning committee. He was singled out by the property developer and paid to influence a planning decision because of past friendship with the corruptor.

Salesman Phil had spent a whole career bribing customers to win contracts. His approach to assessing the risks and opportunities involved building a profile of his targets. He was constantly vigilant for submissive pathogen hints and cues:

'... the more corrupt people in the UK are Asian. If I walked into an office, and I was introduced to the buyer of a project, and he was Asian, Indian, or Pakistani, the chance of him being corrupt were probably better than 50,50 , that he would want something. You knew straightaway, because again it's a culture thing. They come from a poor background, they're in a position of power, they're going to profit by it. The same with Eastern European, you would put them at sort of 20 or 30 per cent. If you saw a picture of the wife and kids on the desk, and a crucifix up on the wall, you sort of knocked it down to five per cent, unless he's putting an act on! If you saw a nice picture of a yacht on the desk, which was bigger than he could have bought on a salary, he's sending you a signal to say, talk to me.' [Phil]

He was also very particular in avoiding the risks associated with high profile targets:

'I was low profile, I dealt with low profile people, I would never do business with anyone who was high profile and corrupt, because the chances of getting caught were high. I dealt with people who were as professional as I was at what they did, and I was fortunate that I could make a very good living without trawling the pond and getting out the dangerous fish. And there's plenty of them around.' [Phil]

\section{Grooming a target}

The grooming phase of the corruption process, if required at all, involves building rapport and pushing the boundaries of a relationship down the 'slippery slope' towards the final act (Köbis et al, 2016). The corruptors manipulate relationships to the point that affective bonds minimise the risks of rejection (Free and Murphy, 2015). At the same time they are constantly watching out for the target's weaknesses. The corruption of Walter was the culmination of months of carefully planned meetings designed to manipulate the relationship into one of perceived friendship whilst patiently waiting for Walter to reveal his vulnerabilities. Eventually Walter provided a necessary piece of the jigsaw by mentioning some minor financial difficulties. This was the cue to initiate the final act of public bribery: 
'And he was saying, "I've got a little something for you [a gift]". I went, "Well, you shouldn't have." And he gets this \#\#\# bag and he says, "It's just a little something, you know, thanks very much." I said, "Well, there's nothing to thank me for."

And he goes, "Oh, there's a little something else." He said, "I know money's tight at the moment.... "...and he takes the bottle out and he tips - and there's $£ \# \# \#$ there - and he said, "There's a little something for you." He said, "I know money's tight at the moment..." So he lent me... as far as I was concerned, he'd lent me \#\#\# quid.

So I've gone in, sat down and he said, "There's a plan I want to show you." And he pulls out \#\#\#\#'s house. Now, the stupid mistake I made was not going, look, I can't discuss this at all, right. As far as I was concerned, here was a friend of mine.' [Walter]

In Phil's view the point of highest risk is when the corrupt offer is made, however 'crossing the Rubicon' into criminality creates the security of mutual assured destruction. He was astonishingly blunt in ensuring co-offenders understood the terms of the arrangement:

'At that point, you then....well I, I can only talk for the way I used to work, I used to say, "Well you've joined an underground army now, we're both at risk, because in the eyes of the law, both the giver and the taker are equally guilty. You're as guilty as me. I'm offering the money, you're taking it, so we're both guilty. So, if you like, we are partners in this now."' [Phil]

A further relevant grooming example is the 'spot fixing' scandal involving Essex cricketer Mervyn Westfield. Westfield was paid $£ 6,000$ by another cricketer, Danish Kaneria, to deliberately bowl badly against Durham in 2009 (Edwards, 2012). Westfield pleaded guilty to accepting the corrupt payment. There was insufficient evidence to prosecute Kaneria, but he was found guilty at a subsequent cricket disciplinary panel and banned from the sport for life (ECB v Kaneria, 2013). In this case Kaneria can be viewed as the 'corrupter pathogen' who recruited Mervyn Westfield, the 'submissive pathogen', a young, impressionable and easily influenced person (ECB v Kaneria, 2013; ESPNCRICINFO, 2012; Westfield, 2013). Kaneria had well documented ties with corrupt groups. He had built up a relationship with Westfield, who was also a neighbour, before raising the possibility of 'spot fixing'. He then maintained pressure on Westfield until he relented. Kaneria used the classical 'everybody is at it' rationalisation and expressed sympathy with the difficulties Westfield faced in getting by on the money he earned. Both Kaneira and Westfield exploited the presence of 'resident pathogens' within the professional cricketing world at the time: the organisational weaknesses within the club and the governing body which were inadequate in promoting integrity, failed to 
deter the players and were unable to prevent the corruption. Westfield was eventually exposed by a whistleblower, fellow cricketer Tony Palladino, following anti-corruption training by the Professional Cricketers' Association (Hoult, 2012).

\section{Financial incentives}

Once a person has been identified as potentially corrupt the next stage is the offering of the incentive to secure participation. For the participants in this study it was monetary, but there are numerous other types of material or service favours which can be offered as alternatives or in combination. Nevertheless, making this offer is the significant risk point for the corruptor. Participant Phil colourfully described how he approached the crucial 'balls on the table' moment:

'I have to tell you, “I'm on commission. If I'm successful in winning this job from you, I would get...l'll probably get about $€ 70,000$ in commission, so that's why it's important that we win it." ..... And then you can, halfway through lunch, say, "I'm quite happy to split that with you." And ...we used to call it, balls on the table, you know the old knife can come down and cut them off, or you can reach across and say, "I'm in."' [Phil]

\section{Coercion}

Coercion may arise when favours or cash bribes are insufficient motivators. It is more likely to be within the armoury of sociopathic corruptors, individuals with the capacity for higher risk taking and less concern for the consequences to others or, indeed, themselves. Those accustomed to criminal lifestyles are likely to fall into this category. James Almond, the prison worker, was approached by an inmate convicted of armed robbery who threatened his family whilst offering bribes worth double his weekly pay for smuggling the phones into prison (Shaw, 2017). The fear of harm and the cash incentives were sufficient motivations to persuade Almond to participate in the crimes.

Research participant, Carl, was also a prison officer. He was targeted by a criminal network to smuggle drugs into prison. Carl declined their first approach and reported the incident to his superiors. However, the management's response was one of indifference. There was no investigation, no risk assessment, no monitoring of the situation nor any support in the anticipation that they might approach Carl again. Two months later he was having a quiet drink with his father in a pub when he was accosted by the same criminals. Faced with the same combination of threat and incentive experienced by James Almond, Carl passed through the veil into corruption:

II was having a drink on a Sunday afternoon with my father, went up to the bar for him and the same two guys were there again saying, "It's your dad downstairs isn't it?" So not only are they threatening me, they're threatening my family now. So I cooperated 
with them give them my phone number and they say, "Okay, when we need stuff we call you, you take it and you be there."' [Carl]

The cultural backdrop which makes bribery easier

In extreme circumstances bribery is a way of life, so deeply embedded in an organisation's culture that any pretence of policies and systems of control are mere window dressing (Brown, Trevino and Harrison, 2005). Brian, Harvey and Phil all worked for businesses which relied on bribery and they were willing participants. The routine activities and systems in their companies were not just infected by pathogens, their failures were so deliberate and advanced that the systems themselves had become mature resident pathogens. Indeed Brian illustrated how training can become a resident pathogen:

'Oh I remember. We used to have training courses in the company ... In ...this was in the 80 's I think, early 90's. A chap used to come in. A consultant used to come in and he would talk about our business. And we used to have role play...he would talk about you and our customer over there, and his big thing was you have to know the difference between subjective and objective needs of your customer. His objective need, yes he wants your product and he has to... you know... His subjective need, he has to look after himself and he also has to make himself look good to his boss. And we were taught all these things about how to make his subjective needs and obviously this included making himself a bit wealthier. You know, this was being taught to us.' [Brian]

Siemens was a highly publicised example of a corrupt organisational culture. Prior to its reforms, active bribery was Siemens' business model (US Department of Justice, 2008). The company's accountancy and control systems were structured resident pathogens that supported and carefully accounted for the corporate bribery using the bland euphemism, 'nützliche Aufwendungen' (useful expenditure) (Schubert and Miller, 2008). Ashforth and Annand (2003) portray such businesses as institutionally corrupt; they normalise bribery and, in accordance with the learning pathway of differential association (Sutherland, Cressey and Luckenbill, 1992, p88), socialise recruits into the organisation's nefarious practices (Ditton, 1977). Emerging awareness of the normalising resident pathogens inherent in an organisation's training, administrative practices, selling and procurement methods thus presents new employees with three strategic choices: leave, turn a blind eye, or construct 'denying the guilty mind' rationalisations (Benson, 1985) and join the community of pathogens, Phil's underground army.

\section{Rationalisation}


Rationalisation is a psychological process which enables otherwise moral people to neutralise the cognitive dissonance stimulated by moral tensions when they engage in immoral conduct (Benson, 1985; Goldstraw-White, 2012; Sykes and Matza, 1957). Neutralising verbalisations appeared in the accounts of all the interviewees. Interestingly, there was a clear division between the types of rationalisations used. The three businessmen, Brian, Harvey and Phil, all excused their conduct as normal, what everybody has to do in business (Benson, 1985). On the other hand, the three bribees in public office attached fault to specific persons. Walter felt he had been solicited unwittingly by his corruptor friend into the bribe which he regarded as a loan, the classic borrowing rationalisation (Cressey, 1953). Carole and Carl both claimed coercion was the cause of their downfalls, a type of rationalisation identified by Daly (1989). Carl also blamed his managers who were indifferent to his plight, a condemnation of his condemners (Benson, 1985).

Sutherland advised, rationalisations can be learned from associates within sub-cultures (Sutherland, Cressey and Luckenbill, 1992, p88). Thus, where rationalisations are tolerated, communally expressed and embedded in organisational cultures, they can become powerful system pathogens which promote frequent, widespread criminality (Shepherd and Button, 2018). The 'normal' rationalisations expressed by the three corruptors reflect views that bribery is an everyday feature of their respective organisations and marketplaces. Phil, the international businessman, was forthright that bribery is a necessary component of commerce in some countries:

'My own view was always....if you don't like it, don't go there. But if you do like it, and you want to go there, and you need the business, then keep your mouth shut and play by the rules.....And we might find their laws archaic and whatever, but they are the laws. And if it's perceived as the way to do business, well then you must be prepared to do it.' [Phil]

Harvey, a property developer, cited the activities of a very senior local politician to illustrate his rationalisations that corruption is normal, widespread and the only way to do business:

'I know a man who used to deliver an envelope to him monthly in cash to his house, so don't start kidding me...' [Harvey]

\section{Implications for prevention}

The bookshelves bend under the weight of the numerous practitioner texts and guides which provide helpful anti-corruption advice (for example, Giles, 2012; Wegner et al, 2013). There is also a certifiable international standard, BS ISO 37001: 2016 Anti-Bribery Management System, which 
organisations can implement to demonstrate compliance with the Bribery Act 2010. Many of these publications address both fraud and bribery because the two crimes share common characteristics including abuse of position, breach of trust, secrecy, environmental opportunities, motivations, rationalisations and methods (Brytting, Minogue and Morino, 2011, pxxii). However, there is very little evidence of the effectiveness of these methods (Hafner et al, 2016, p23), possibly because they are dominated by management tools designed for routine financial control and asset protection (Gordon and Miyake, 2000). More recently, a number of scholars have advocated the utility of situational crime prevention (Cornish and Clarke, 2003) in the analysis of corruption because, in contrast to more generalised theories and approaches, it pays attention to the specific circumstances and scripts of situations (Graycar and Prenzler, 2013; Tunley et al, 2017).

This paper has illustrated that the necessary ingredients for bribery to occur in these situations is the convergence of human and resident pathogens. The pathogen network analysis illustrated in Figure 2 is a visualisation tool for examining the relationships between these pathogens in actual or potential corrupt situations. It assists retrospective learning from actual events by mapping the connections between the human pathogens, who decided on a corrupt course of action, and the resident system pathogens which enabled the act. It also enables managers to prioritise the implementation of remedies by visually locating and ranking the pathogen risks.

The corruption pathogen model suggests that organisations should endeavour to avoid human pathogens in the first place, especially the assertive corruptor pathogens who pose the greatest threat, using due diligence and recruitment screening methods. Organisations should also tease out resident pathogens within their cultures and control systems to bolster their defences against emerging or cemented corrupt relationships. Walter's and Carl's stories illustrate the importance of disrupting the grooming processes which may lead to powerful social bonds, coercion or blackmail. Sometimes avoiding predatory corruptor pathogens can be deceptively straightforward, simply requiring that so-called 'red flags' are not ignored (Shaw and Fischer, 2005; Button and Gee, 2013, p42, 91). Walter's council, for example, ought to train its councillors, especially those on the planning committee, to recognise and report bribery signals that preface the slippery slope of corruption. Carl's prison needs to train its managers to heed corruption warnings and develop robust response plans with appropriate security measures that support targeted members of staff.

By applying the pathogen network prospectively, corruption risks can be anticipated and controlled. Networks centred on each job role illuminate the associated pathogen risks and promote challenging reflections on the trajectory of corruption opportunities. Reflecting Phil's case, are the sales incentives so large that the sales manager can afford to assertively bribe customers using his own 
money? How would the procurement processes resist exploitation by a corruptor, like Brian, and a financially distressed engineering manager? Are the regulators, such as Walter, trained to spot grooming techniques? Should the organisation even deal with organisations encumbered by a corrupt track record like Siemens? Are the existing due diligence and recruitment screening processes adequate for all situations?

Not every role in an organisation is susceptible to corruption risks. Nevertheless, the risks are not confined to senior roles or the more obvious positions have authority over monetary or regulatory transactions. Carl and Carole were junior prison officers and James Almond had a support role, escorting contractors into prisons (Shaw, 2017). Li attempted to bribe his professor (BBC, 2013) and the first person convicted under the Bribery Act 2010 was a clerk whose role involved entering information onto a court database (BBC, 2011). The pathogen network approach can be used to highlight which roles and relationships should be prioritised for in depth initial due diligence or recruitment screening, continuous monitoring or tightened controls (Button and Gee, 2013, p59; Risk Advisory Group, 2017). A complete analysis for each role and relationship includes all five dimensions set out in this paper: the four human dimensions covering the corruptor pathogen, the submissive pathogen (or second corruptor), the briber and the bribe, and the resident pathogens within the organisation's control systems.

A positive aspect that can be drawn from all the cases introduced in this paper is that they were all exposed following complaints. The Westfield case is particularly notable because the investigations were triggered by a whistleblowing report from a colleague following anti-corruption training by the Professional Cricketers' Association (PCA). This incident highlights how training and support is necessary to make whistleblowing systems effective. A key element of this training is tackling the rationalisations which open the psychological pathway to corruption (Cressey, 1953). Following Shepherd and Button (2018), rationalisations become infectious resident pathogens when they are tolerated and embedded within an organisation's culture. Dismantling these rationalisations serves two purposes based in developing positive normative values. Firstly, it helps to deter some people who may contemplate engaging in corruption (Nettler, 1974, Cressey, 1986). All of the research participants verbalised rationalisations for their criminality in terms of borrowing, coercion or normality (Table 1). It is not known what impact such training would have had on the six participants. However, it is reasonable to argue that dismantling rationalisations is likely to affect submissive pathogens more positively than assertive corruptors. This hypothesis is worthy of further research. The second purpose, as illustrated by the PCA training, is that dismantling rationalisations encourages whistleblowing by informing colleagues that there is no legitimate excuse for corruption. 


\section{Conclusions}

This paper has examined the social interactions and settings involved in the perpetration of a small sample of bribery cases using a novel approach, the metaphor of pathogens. The paper has demonstrated how corruptor pathogens recruit other human pathogens using profiling, grooming, financial incentives and coercion. The key theoretical proposition is that the situational pathway to the act of bribery must involve the convergence of at least three pathogens and at least two types. There must be at least two human pathogens: a human 'corruptor pathogen' who offers or seeks a bribe and a corresponding, sufficiently motivated 'submissive pathogen' (or a second corruptor pathogen). There must also be at least one 'resident pathogen' or weakness within the organisation's culture or control systems. The pathogen network model visually represents these pathogens as connected nodes.

The pathogen model is a simple tool for both researchers and practitioners. It sets out a framework for positivist research into the aetiology of bribery and other workplace crimes. It can also be linked into existing crime theories such as situational crime prevention (Cornish and Clark, 2003) and rationalisation theory (Cressey, 1953). Behaviourists can deploy it to investigate how social learning and conditioning draws otherwise moral persons into corrupt corporate practices (Ashforth and Annand, 2003). It provides practitioners and corporate managers with a tool to bolster organisational resilience, particularly when used in conjunction with existing risk assessment and prevention practices (Button and Gee, 2013). It has the capacity to support organisations in both prospective crime risk analyses and retrospective causal diagnoses. The key to preventing bribery is preventing corruptor pathogens from being employed in or working with an organisation in the first place; and then creating a resilient management environment with few resident pathogens and submissive pathogens that can be exploited by any remaining corruptor pathogens.

\section{References}

Ashforth, B. and Anand, V. (2003). The normalization of corruption in organizations. Research in Organizational Behavior, 25, 1-52.

BBC (2011, November 18). Court clerk Munir Patel jailed for taking bribes. BBC. Available at: http://www.bbc.co.uk/news/uk-england-london-15689869 
BBC (2013, April 23). University of Bath student jailed over tutor bribe bid. BBC. Retrieved from: http://www.bbc.co.uk/news/uk-england-somerset-22269573

Benson, M. (1985). Denying the guilty mind: Accounting for involvement in a white-collar crime. Criminology, 23(4), 583-607.

Benson, M. (1990). Emotions and adjudication: Status degradation among white-collar criminals. Justice Quarterly, 7(3), 515-528.

Benson, M. and Cullen, F. (1988). The special sensitivity of white collar-offenders to prison: A critique and research agenda. Journal of Criminal Justice, 16, 207-215.

Brown, M., Trevino, L. and Harrison, D. (2005). Ethical leadership: a socio learning perspective for construct development and testing. Organisational Behaviour and Human Decision Processes, 97, 117-134.

Brytting, T., Minogue, R. and Morino, V. (2011). The Anatomy of Fraud and Corruption:

Organizational Causes and Remedies. Farnham: Gower.

Bunn, M. and Sagan, S. D. (Eds.). (2016). Insider Threats. Cornell University Press.

Burke, R. (2010). Crime and corruption in organizations. In R. Burke, E. Tomlinson and C. Cooper (Eds.). Crime and Corruption in Organizations: Why It Occurs and What to Do about It. Farnham: Ashgate.

Button, M. and Gee, J. (2013). Countering fraud for competitive advantage. Chichester: Wiley.

Carley, K. (1997). Network Text Analysis: The Network Position of Concepts. In C. W. Roberts (ed.), Text Analysis for the Social Sciences. Hillsdale, NJ: Lawrence Erlbaum, p79-100.

Coleman, J. (1992). The theory of white-collar crime: from Sutherland to the 1990s. In K. Schlegel and D. Weisburd, White-collar crime reconsidered. Boston: Northeastern University Press.

Copes, H. and Hochstetler, A. (2010). Interviewing the incarcerated: Pitfalls and promises. In W. Bernasco (ed.), Offenders on offending: Learning about crime from criminals, p49-67. London: Routledge.

Cornish, D. and Clarke, R. (2003). Opportunities, precipitators and criminal decisions: a reply to Wortley's critique of situational crime prevention. Crime Prevention Studies, 16, 41-96.

CPS (2016, August 9). Six found guilty of corruption in relation to Royal Household contracts. Retrieved from: 
http://www.cps.gov.uk/news/latest_news/six_found_guilty_of_corruption_in_relation_to_royal_ho usehold_contracts/

Cressey, D. (1953). Other People's Money. Belmont, CA: Wadsworth Publishing.

Cressey, D. (1986). Why managers commit fraud. Australian and New Zealand Journal of

Criminology, 19,195-209.

Daly, K. (1989). Gender and varieties of white-collar crime. Criminology, 27, 769-793.

Ditton, J. (1977). Part-Time Crime: An Ethnography of Fiddling and Pilferage. London: MacMillan.

EC (2013). Identifying and reducing corruption in public procurement in the EU. Retrieved

from:http://ec.europa.eu/anti_fraud/documents/anti-fraud-policy/research-and-

studies/identifying_reducing_corruption_in_public_procurement_en.pdf

ECB v Kaneria (2013). Determination of the Appeal Panel of the Cricket Disciplinary Commission of the England and Wales Cricket Board. ECB. Available at: https://www.ecb.co.uk/news/79242

Edwards, R. (2012, Feb 17). Mervyn Westfield sentenced to four months in jail after being found guilty of spot-fixing. The Telegraph. Available at:

http://www.telegraph.co.uk/sport/cricket/counties/9088222/Mervyn-Westfield-sentenced-to-fourmonths-in-jail-after-being-found-guilty-of-spot-fixing.html

Eicher, S. (ed.) (2012). Corruption In International Business: The Challenge of Cultural and Legal Diversity. Farnham: Ashgate.

ESPNCRICINFO (2012). Full transcript of Kaneria, Westfield hearing. Available at:

http://www.espncricinfo.com/ci/content/story/569429.html

Fletcher, C. and Herrmann, D. (2012). The Internationalisation of Corruption: Scale, Impact and Countermeasures. Farnham: Gower.

Free, C. and Murphy, P. (2015). The ties that bind: The decision to co-offend in fraud. Contemporary Accounting Research, 32(1), 18-54.

Giles, S. (2012). Managing fraud risk: a practical guide for directors and managers. Chichester: Wiley.

Goldstraw-White, J., E. and Gill, M. (2016) Tackling Bribery and Corruption in the Middle East: perspectives from the front line. Journal of Financial Crime, 23(4), 843-854

Goldstraw-White, J. (2012). White Collar Crime Accounts of Offending. Basingstoke: Palgrave. 
Gordon, K. and Miyake, M. (2000). Business approaches to combating bribery: A study of codes of conduct, OECD Working Papers on International Investment, 2000/01. OECD Publishing.

Gottschalk, P. (2017). Empirical Study of Convenience Theory: A Student Elicitation on White-Collar Crime. Deviant Behavior, 1-11.

Gottschalk, P. and Tcherni-Buzzeo, M. (2017). Reasons for gaps in crime reporting: The case of whitecollar criminals investigated by private fraud examiners in Norway. Deviant Behavior, 38(3), 267-281.

Gray, G. (2013). Insider Accounts of Institutional Corruption. British Journal of Criminology, 53: 533551.

Graycar, A. and Prenzler, T. (2013). Understanding and preventing corruption. Basingstoke: Palgrave MacMillan.

Graycar, A. and Sidebottom, A. (2012). Corruption and control: a corruption reduction approach. Journal of Financial Crime, 19(4), 384-399.

Hafner, M., Taylor, J., Disley, E., Thebes, S., Barberi, M., Stepanek, M. and Levi, M. (2016). The cost of non-Europe in the area of organised crime and corruption - Annex II. Brussels: European Union. Retrieved from:

http://www.europarl.europa.eu/RegData/etudes/STUD/2016/579319/EPRS_STU\%282016\%2957931 9_EN.pdf

Hernandez, T. and McGee, R. (2013). Ethical attitudes toward taking a bribe: a study of three Latin American countries. International Journal of Business and Economics Perspectives, 8(1), 142-166.

Hoult, N. (2012, April 18). I forgive Mervyn Westfield, says spot-fixing whistleblower Tony Palladino. The Telegraph. Available at: http://www.telegraph.co.uk/sport/cricket/9212508/I-forgive-MervynWestfield-says-spot-fixing-whistleblower-Tony-Palladino.html Kalof, L., Dan, A. and Dietz, T. (2008). Essentials of social research. Maidenhead: Open University Press.

Köbis, N. C., van Prooijen, J. W., Righetti, F. and Van Lange, P. A. (2016). The road to bribery and corruption: Slippery slope or steep cliff? Psychological Science, 1-10. Retrieved from:

https://doi.org/10.1177/0956797616682026

Kubbe, I. and Engelbert, A. (eds) (2018). Corruption and Norms. Basingstoke: Palgrave. 
Le blond, J. (2014, August 5). Bernie Ecclestone: 'I'm an idiot' for paying f60m to settle F1 bribery trial. The Guardian. Retrieved from: http://www.theguardian.com/sport/2014/aug/05/formula-onebernie-ecclestone-idiot-paying-100m-dollars-settle-bribery-trial

Lord, J. (2014). Regulating corporate bribery in international business: Anti-corruption in the UK and Germany. Aldershot: Ashgate.

Lord, J. and Levi, M. (2016). Organizing the finances for and the finances from transnational corporate bribery. European Journal of Criminology, 1-25. Retrieved from:

https://doi.org/10.1177/1477370816661740

Mars, G. (1982). Cheats at Work: Anthropology of Workplace Crime. London: Allen and Unwin. Mazar, N., Amir, O. and Ariely, D. (2008). The dishonesty of honest people: A theory of self-concept maintenance. Journal of marketing research, 45(6), 633-644.

Melgar, N., Rossi, M. and Smith, T. (2010). The perception of corruption. International Journal of Public Opinion Research, 22(1), 120-131.

Middleton, D. and Levi, M. (2015). Let sleeping lawyers lie: organized crime, lawyers and the regulation of legal service. British Journal of Criminology, 55, 647-668.

MoJ (2011). The Bribery Act 2010: guidance. Retrieved from:

https://www.gov.uk/government/publications/bribery-act-2010-guidance

MoJ (2016). Experimental statistics on proceedings and outcomes by Home Office offence code. Retrieved from: https://www.gov.uk/government/statistics/criminal-justice-system-statisticsquarterly-december-2015

Nash, R., Bouchard, M. and Malm, A. (2017). Social networks as predictors of the harm suffered by victims of a large-scale Ponzi scheme. Canadian Journal of Criminology and Criminal Justice, 59(1), 26-62.

Nettler, G. (1974). Embezzlement without problems. British Journal of Criminology, 14, 70-77.

OECD (2011). Convention on Combating Bribery of Foreign Public Officials in International Business Transactions. Retrieved from: http://www.oecd.org/daf/anti-bribery/ConvCombatBribery_ENG.pdf OECD (2014). The rationale for fighting corruption. Retrieved from: https://www.oecd.org/cleangovbiz/49693613.pdf 
Peoples, C. and Sutton, J. (2015). Congressional bribery as state-corporate crime: A social network analysis. Crime, Law \& Social Change, 64, 103-125.

Perrow, C. (2011). Normal accidents: Living with high risk technologies. Princeton University Press.

Reason, J. (2000a). Human error: models and management. British Medical Journal, 320(7237), 768770.

Reason, J. (2000b). Safety paradoxes and safety culture. Injury Control \& Safety Promotion, 7(1), 314.

Risk Advisory Group (2017). CV Lies 2017. London: Risk Advisory Group.

Schoepfer, A., Piquero, N. L. and Langton, L. (2014). Low self-control versus the desire-for-control: An empirical test of white-collar crime and conventional crime. Deviant Behavior, 35(3), 197-214.

Schubert, S. and Miller, M. (2008, December 21). At Siemens, bribery was just a line item. New York Times. Retrieved from:

http://www.nytimes.com/2008/12/21/business/worldbusiness/21siemens.html?_r=1\&pagewanted $=$ print

Schuchter, A., and Levi, M. (2013). The fraud triangle revisited. Security Journal, 29(2), 107-121.

Shaw, D. (2017, March 14). Prison smuggler: 'I brought mobile phones in for criminals'. BBC.

Available at: http://www.bbc.co.uk/news/uk-39258076

Shaw, E. D. and Fischer, L. F. (2005). Ten tales of betrayal: The threat to corporate infrastructure by information technology insiders analysis and observations (No. PERS-TR-05-13). Monterey: Defense Personnel Security Research Center.

Shepherd, D. and Button, M. (2018). Organizational inhibitions to addressing occupational fraud: A theory of differential rationalization, Deviant Behavior, DOI: 10.1080/01639625.2018.1453009

Slapper, G. and Tombs, S. (1999). Corporate Crime. Harrow: Longman.

Sutherland, E. (1940). White-collar criminality. American Sociological Review, 5(1), 1-12.

Sutherland, E., Cressey. D. and Luckenbill, D. (1992). Principles of criminology (11th ed.). Lanham: General Hall.

Sykes, G. and Matza, D. (1957). Techniques of neutralization: A theory of delinquency. American Sociological Review, 22, 664-670.

Toft, B. and Reynolds, S. (1997). Learning from Disasters. Leicester: Perpetuity Press. 
Transparency International (2018). Corruption Perceptions Index. Berlin: Transparency International. Available at:

https://www.transparency.org/news/feature/corruption_perceptions_index_2017\#resources

Transparency International, (u.d.). Anti-corruption glossary. Available at:

https://www.transparency.org/glossary/

Tunley, M., Button, M., Shepherd, D. and Blackbourn, D. (2018). Preventing occupational corruption: utilising situational crime prevention techniques and theory to enhance organisational resilience. Security Journal, 31(1), 21-52.

United Nations (2013). A guide for anti-corruption risk assessment. Retrieved from: https://www.unglobalcompact.org/library/411

US Department of Justice (2008). US DoJ sentencing memorandum. Retrieved from the US Department of Justice website: http://www.justice.gov/opa/documents/siemens-sentencingmemo.pdf

Van Mastrigt, S. and Farrington, D. (2009). Co-offending, age, gender and crime type: Implications for criminal justice policy. British Journal of Criminology, 49(4), 552-573.

Van Slyke, S., Benson, M. and Cullen, T. (eds.). (2016). The Oxford Handbook of White-collar Crime. Oxford: OUP.

Vicsek, L., Kiraly, G. and Konya, H. (2016). Networks in the social sciences: comparing actor-network theory and social network analysis. Corvinus Journal of Sociology and Social Policy, 7(2), 77-102.

Wegner, S., Schoberlein, J. and Biermann, S. (2013). Motivating business to counter corruption: a practitioner handbook on anti-corruption incentives and sanctions. Berlin: Humboldt-Viadrina School of Governance. Retrieved from: http://www.governance-platform.org/wpcontent/uploads/2015/01/HVSG_ACIS_PractitionerHandbook_20131121.pdf

Welsh, D. T., Ordóñez, L. D., Snyder, D. G. and Christian, M. S. (2015). The slippery slope: How small ethical transgressions pave the way for larger future transgressions. Journal of Applied Psychology, 100(1), 114.

Westfield, M. (2013). Mervyn Westfield's Story. https://www.youtube.com/watch?v=tMYYafUCxPw Wilson, J. (2014, March 3). Mervyn Westfield: Banned spot-fixing cricketer seeks redemption. BBC. Retrieved from: http://www.bbc.co.uk/sport/cricket/26405494 
Wolfe, D. and Hermanson, D. (2004). The fraud diamond: considering the four elements of fraud. The CPA Journal, 74(12), 38-42. 
Table 1: Interview participants

\begin{tabular}{|c|c|c|c|c|c|c|}
\hline Pseudonym & Gender & Age & Script & Bribery type & Classification & $\begin{array}{c}\text { Primary } \\
\text { rationalisation }\end{array}$ \\
\hline Walter & $M$ & $40-59$ & $\begin{array}{l}\text { Councillor - took bribes for } \\
\text { planning permits }\end{array}$ & Public bribery & $\begin{array}{l}\text { Submissive bribee - } \\
\text { submissive pathogen }\end{array}$ & Borrowing \\
\hline Carl & M & $20-39$ & $\begin{array}{l}\text { Prison officer - coerced and } \\
\text { took bribes for smuggling } \\
\text { drugs into prison }\end{array}$ & Public bribery & $\begin{array}{l}\text { Submissive bribee - } \\
\text { submissive pathogen }\end{array}$ & Coercion \\
\hline Carole & $\mathrm{F}$ & $40-59$ & $\begin{array}{l}\text { Prison officer - coerced and } \\
\text { offered bribes }\end{array}$ & Public bribery & $\begin{array}{l}\text { Submissive bribee - } \\
\text { submissive pathogen }\end{array}$ & Coercion \\
\hline Harvey & $M$ & $60+$ & $\begin{array}{l}\text { Property developer - paid } \\
\text { bribes for projects }\end{array}$ & $\begin{array}{l}\text { Public bribery, } \\
\text { commercial bribery }\end{array}$ & $\begin{array}{l}\text { Assertive briber - } \\
\text { corruptor pathogen }\end{array}$ & Normal \\
\hline Phil & $M$ & $60+$ & $\begin{array}{l}\text { International salesman - } \\
\text { paid bribes for supply } \\
\text { contracts }\end{array}$ & $\begin{array}{l}\text { Public bribery, } \\
\text { commercial bribery }\end{array}$ & $\begin{array}{l}\text { Assertive briber - } \\
\text { corruptor pathogen }\end{array}$ & Normal \\
\hline Brian & $M$ & $60+$ & $\begin{array}{l}\text { Company director - } \\
\text { authorised bribes for supply } \\
\text { contracts }\end{array}$ & Commercial bribery & $\begin{array}{l}\text { Assertive briber - } \\
\text { corruptor pathogen }\end{array}$ & Normal \\
\hline
\end{tabular}

Figure 1: Simple pathogen network

(C) Corruptor pathogen

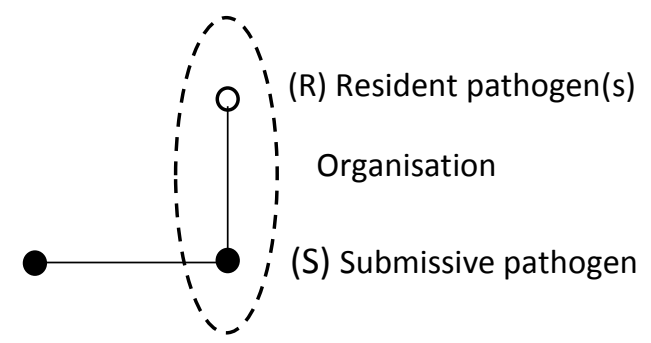


Figure 2: Pathogen network centred on 'Carl'

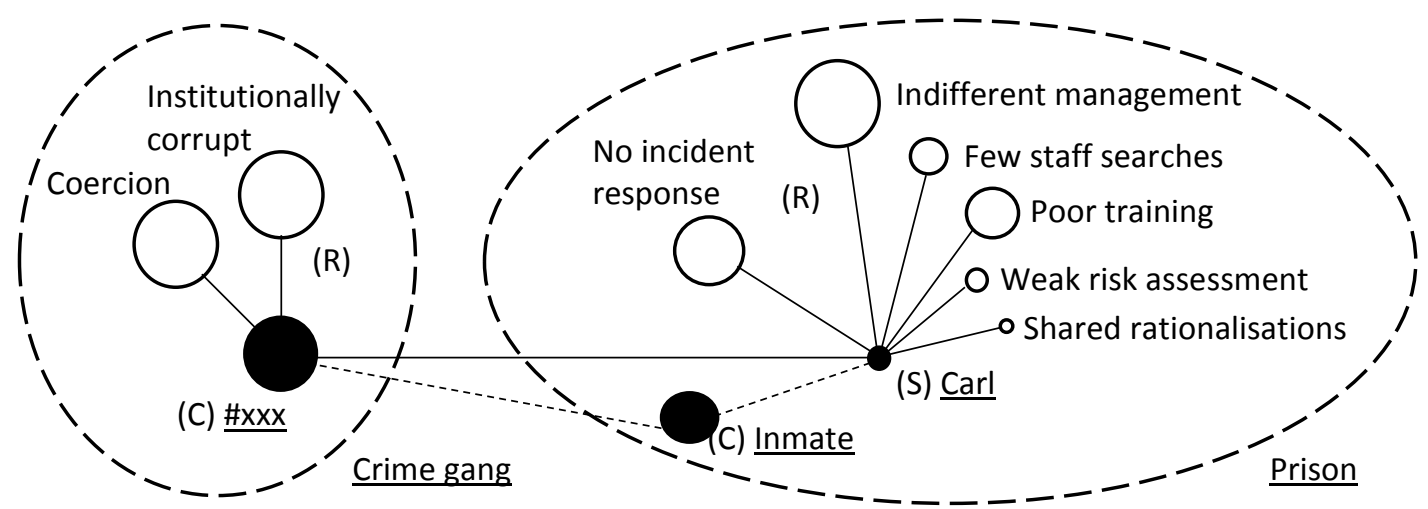

